\title{
A Magyar Lloyd Repülőgép és Motorgyár Rt. története
}

A z 1914-es év a világtörténelem egyik fontos állomása. A közelgő Nagy Háború szele a monarchia országait, településeit, többek között Aszódot is elérte. A háborús törekvések pártolóinak kitűnő lehetőséget biztosított az első világégés csírájának elvetésére. A háborús felfegyverkezés szolgálatába álítása céljával 1913-ban megalakult a Magyar Lloyd Atomobil és Motorgyár Rt., ami a 1914 tavaszi névváltoztatás után a Magyar Lloyd Repülőgép és Motorgyár Rt. nevet vette fel.

A magyarországi Lloyd gyár történetének kezdete 1913 januárjára tehető, amikor Heirich Bier, a lipcsei Deutsche Flugzeug Werke (DFW) technikai igazgatója egy DFW monoplánnal bemutatót tartott Fischamendben. Bier befolyásos embernek számított akkoriban, és ezáltal közvetlen kapcsolatot tartott fenn a bécsi katonai körökkel. Bier engedélyt kapott a hadügyminisztériumtól, hogy a DFW leányvállalatot alapíthasson Magyarországon. Így a Lloyd alapítása után egy évvel, 1914. április 30-ától a DFW bevonásával megkezdődött a magyarországi gyár története [5]. „Ez a gyár tipikus példája volt a hadiipar igényei nyomán jelentkező külföldi tőkebeáramlásnak. A közelgő háborús készülődések profitlehetősége arra késztette a hazai tőkéscsoportokat, hogy repülőgépipart hozzanak létre, és a várható hasznok növelésére alaptőkéjüket külföldi tőkebefektetésekkel is növeljék. A magyar repülőgépipar haszonélvezői között így egyaránt megtaláljuk az ebben az időben kapitalizálódó nagybirtokosokat, arisztokratákat és a velük szövetkező külföldi nagytőkéseket" [3].

A gyár két vezetője kezdetben Henrik Bier szolgálaton kívüli ulánus főhadnagy, valamint dr. Urbach Lajos ügyvéd volt. Ők látták el a vezetői feladatokat, valamint komoly kutatásokat folytattak az aviatika területén.

A későbbi munkálatok során egyre inkább Henrik Bier kezébe került át a gyár irányítása, aki a repülőkísérleti és berepülő feladatokat is ellátta. Bier a gyár főmérnökének és a tervezőiroda vezetőjének a korábban Bánki Donát professzorhoz kötődő Melczer Tibort hívta meg, akinek a munkáját Szalay Ferenc és Tóbiás Béla mérnökök segítették. (A három mérnök és öt műszaki rajzoló szerény tervezési kapacitást biztosított csupán. - Szerk.)

A háború első éveiben a Lloyd gyár elsősorban a saját fejlesztésű repülőgép prototípusokra támaszkodott, ebben az időszakban 20 kísérleti repülőgépet építettek. A sorozatgyártás ekkor még nem volt jelentős. A gyár működése során a 20 kísérleti repülőgépből csupán 8-at gyártott sorozatban, abból hármat német licenc alapján. Az aszódi gyár mérnökségén dolgozók sok új szabadalmi bejelentést tettek, vagy technológiai újítást nyújtottak be, ezzel is hozzájárulva a gyár sikereihez. Talán a legjelentősebb ilyen újítás Melczer Tibor nevéhez füződik. Ez pedig a szárny furnérral való bevonása volt. Rájött, hogy nemcsak a törzset lehet bevonni, hanem a repülőgép szárnyait is. Ennek az eredménye egy sokkal simább és egyenletesebb profilú, a textilborítású szárnyaknál masszívabb konstrukció lett.

Szabadalommal védett megoldása a Llyod C V típusokon került sorozatgyártásra. Felépítése a következő volt: a szárnypaneleket több, keresztirányban elhelyezkedő tartógerenda alkotta, amelyeket egyenlő távolságra helyeztek el a hosszanti szárnybordák körül. Ezt a rácsszerkezetet kívülről jól felpolírozott, 1,2 mm vastagságú furnérlemezzel borították. A Lloyd gyár ezzel a mesteri húzással indította meg a repülőgépgyártásban a törzs- és a szárnyfelületek tömör anyaggal való borítását [5].

\section{A REPÜLőGÉPGYÁRTÁS KEZDETE}

A gyár első munkája a Németországból alkatrészekben érkezett 10 darab DFW B I kétüléses, biplán összeszerelése volt. Ez idő tájt kezdődött meg a tényleges gyártás is, az
ÖSSZEFOGLALÁS: 1913-ban megalakult a Magyar Lloyd Atomobil és Motorgyár Rt., ami 1914-ben a Magyar Lloyd Repülőgép és Motorgyár Rt. nevet vette fel. A cég - repülögyártás szempontjából - a lipcsei Deutsche Flugzeug Werke (DFW) leányvállalata volt Magyarországon. A háború első éveiben a Lloyd gyár inkább a saját fejlesztésú repülőgép prototípusokra támaszkodott, ebben az időszakban 20 kísérleti repülőgépet építettek. Ezek közül végül ötöt gyártott sorozatban, hármat pedig német licenc alapján.

KULCSSZAVAK: I. világháború, Magyar Lloyd Repülőgép és Motorgyár Rt., Deutsche Flugzeug Werke, repülöipar
ABSTRACT: In 1913, the Hungarian Lloyd Automobile and Motor Factory Co. (Magyar Lloyd Automobil és Motorgyár Rt.) was founded and then, in 1914, its was named to Hungarian Lloyd Aircraft and Motor Factory Co. (Magyar Lloyd Repülőgép és Motorgyár Rt.). In terms of aircraft manufacturing, the firm in Hungary was a subsidiary of the Deutsche Flugzeug Werke (DFW) in Leipzig. In early years of the war, main activities of the Lloyd factory were directed to develop own aircraft prototype. In this period 20 experimental aircraft were built. Five of them was manufactures in series and three pieces was built under German licence.

KEY WORDS: World War I, Magyar Lloyd Repülőgép és Motorgyár Rt., Deutsche Flugzeug Werke, aircraft industry

\footnotetext{
* Óbudai Egyetem, Műszaki Biztonságtudományi Szakműhely, BSc hallgató, Óbuda University, Institute of Mechatronics and Vehicle Engineering hrvt.fruzsina@gmail.com, Orcid: 0000-0002-3072-9623

** Óbudai Egyetem, Bánki Donát Gépész és Biztonságtechnikai Mérnöki Kar, oktatási igazgató, Óbuda University, Donát Bánki Faculty of Mechanical and Safety Engineering, moharos.istvan@bgk.uni-obuda.hu, Orcid: 0000-0002-0520-4059

*** Óbudai Egyetem, Mechatronikai és Járműtechnikai Intézet, egyetemi tanár, Óbuda University, Institute of Mechatronics and Vehicle Engineering, pokoradi.laszlo@bgk.uni-obuda.hu Orcid: 0000-0003-2857-1887
} 


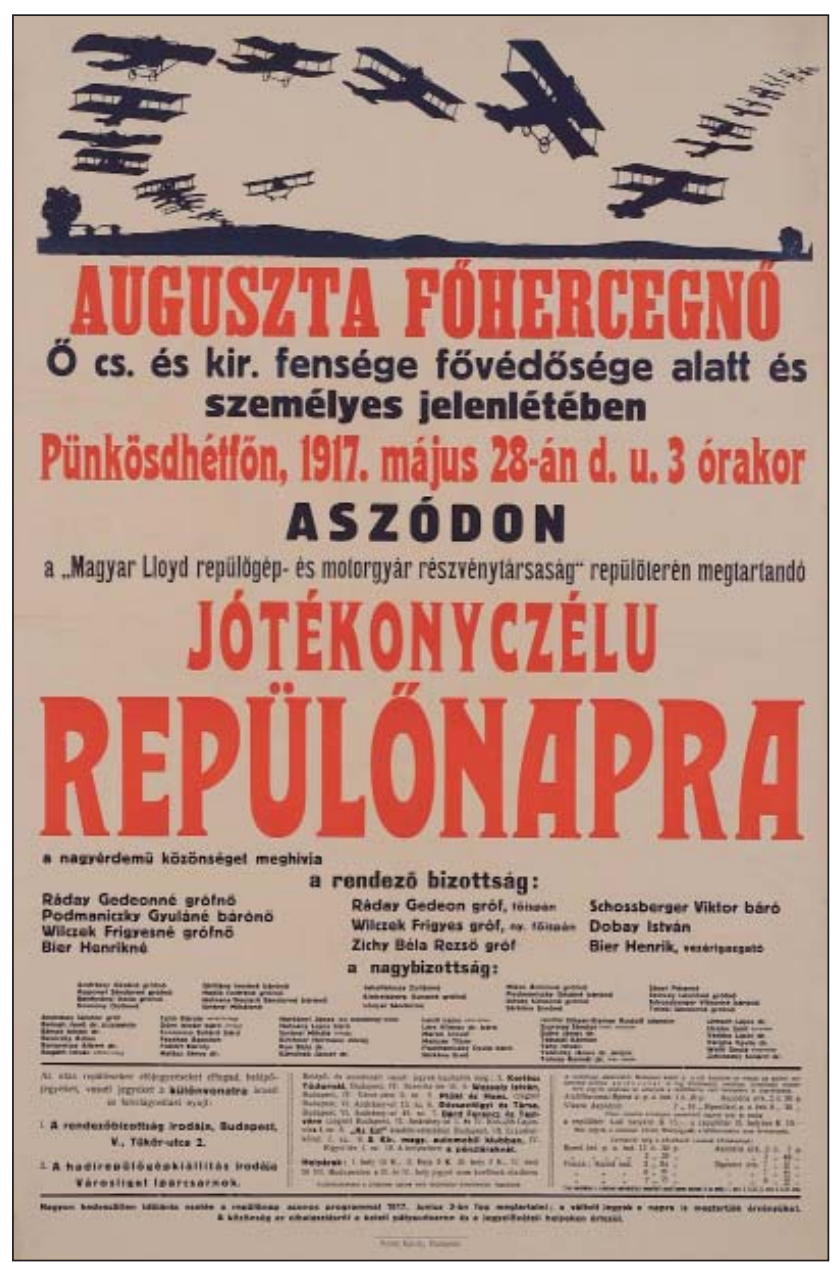

1. ábra. Az 1917. május 28-i repülőnap plakátja

első gépen nagyon sok jól képzett szakember dolgozott, akiket még a Ducker gyárban alkalmaztak. A gépet végül 40.01-es számmal látták el. A gép maga acélcsőváz szerkezetű törzzsel rendelkezett, valamint a szárnyakat selyemmel vonták be.

A jó repülőtulajdonságokkal rendelkező gép szárnyainak kialakítása komplikált volt (a szárnyak görbe ívben hátrahajlottak, ezért ezt a konstrukciót „Repülő banán” néven emlegették), ezért Melczer Tibor áttervezte. Az átdolgozott repülőgép-konstrukció könnyebben gyártható egyenes lécekből épített, hátranyilazott formával könnyebb, kétcellás szárnyszerkezettel, de az eredeti törzs megtartásával készült. A DFW mintagéptől eltérően a törzs nem acélcső szerkezetű volt, hanem fából épült. Az átalakított Lloyd LS1-es néven szereplő gép könnyebb lett, mint a DFW B I.

Hatalmas várakozás övezte az első gép próbarepülését. A berepülésre egy fiatal külföldi mérnököt kértek fel, azonban a gép első útja katasztrófával végződött: a gép repülés közben az oldalára dőlt és végül a földre zuhant. A German and Austro-Hungaraian Aircraft Manufacturers című könyv arról számol be, hogy ebben a szerencsétlen balesetben a pilóta életét vesztette, bár ezt más forrás nem támasztotta

2. ábra. Repülögép rajtvonal 1917. május 28.

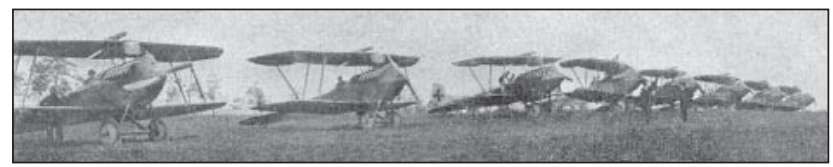

alá.[6] Ez a szerencsétlen első szárnypróbálgatás azonban nem a gépezet számlájára írható, hanem emberi mulasztás okozta. A csűrőkormányokat fordítva kötötték be, s ez okozta a bedőlést.

\section{A VIRÁGKOR}

A próbarepülést követően a kijavított gépet Ausztriába szállították, ahol egy nemzetközi repülőtalálkozón sikerült megdöntenie két világrekordot is. A gép pilótája ekkor Henrik Bier volt. Neki sikerült 1914. június 27-én először, egyedüli emelkedéssel elérni a 6170 méteres magasságot, azután pedig másodmagával 5440 métert ért el. Az új gép sikere láttán a monarchia egyből meg is bízta a gyárat egy darab prototípus, valamint tizenkét darab szériagép legyártásával. Ezeknek a gépeknek az alapját az LS-1-es adta, s végül a Lloyd C.I. nevet kapták.

Mindezek után elkezdődtek a gyár bővítésével kapcsolatos munkálatok is. Hatalmas területeket vásároltak, ahol új műhelyeket és kisebb épületeket hoztak létre. Megkezdték a 40.01-es gép sorozatgyártását (7. ábra), Lloyd C.I. (41. sorozat) néven.

Kezdetben a gépek berepülése az asperni repülőtéren történt, azonban ez meglehetősen költségessé tette a gyártást. A gyár igazgatósága egy Aszódon létesítendő repülőtér megnyitásában látta a megoldást. A gyár ezután több holdnyi területet vásárolt, ahol kialakították a berepüléshez szükséges övezetet.

Az elkészült gépek átadása a berepülés után történt meg. A reptérre érkeztek a pilóták, ahonnan elvitték a gépeket a megrendelés helyére. Néha vasúton is szállították az elkészült repülőket, ami ugyancsak ideális volt, mivel épp a berepülési zóna mögött húzódott a Budapest - Miskolc vasútvonal.

Ekkoriban Aszódon rengeteg neves pilóta megfordult, akik szakértelmükkel mind hozzájárultak a gyár sikeréhez. Legfőképp Siegler Albertet kell megemlíteni, nagyon sokáig ő volt a gyár főpilótája, de többek mellett Fehér Antal, Kurtnecker Árpád, Minár Gyula, Lányi Antal is a korszak neves pilótái voltak.

1916-tól kezdődően hetente két-három gépet bocsátottak ki, ami igencsak nagy teljesítmény volt, akkoriban csak a Magyar Repülőgépgyár Rt. rendelkezett nagyobb terme-

3. ábra. 1917. május 28-i repülőnap - Ferenc föherceg készül a felszállásra

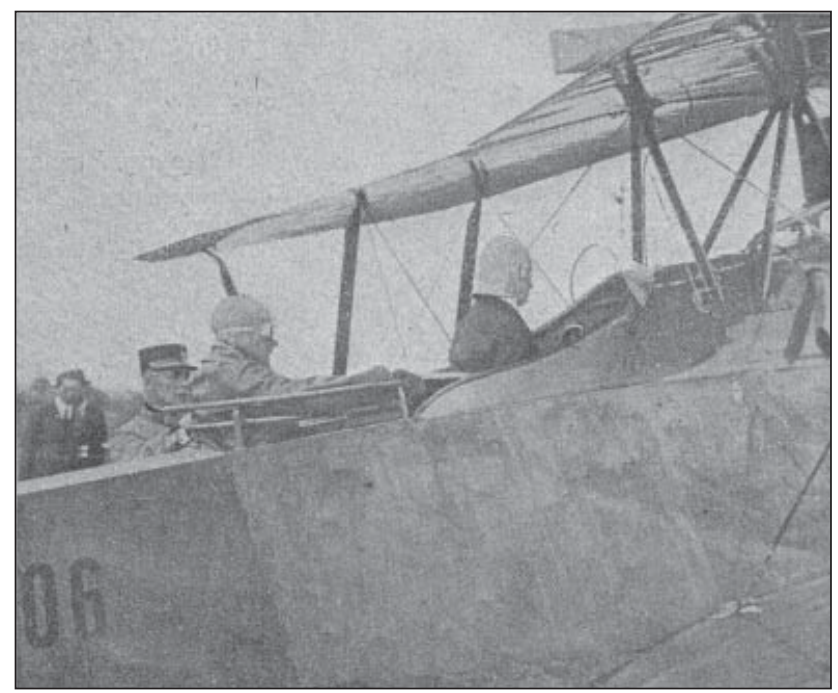




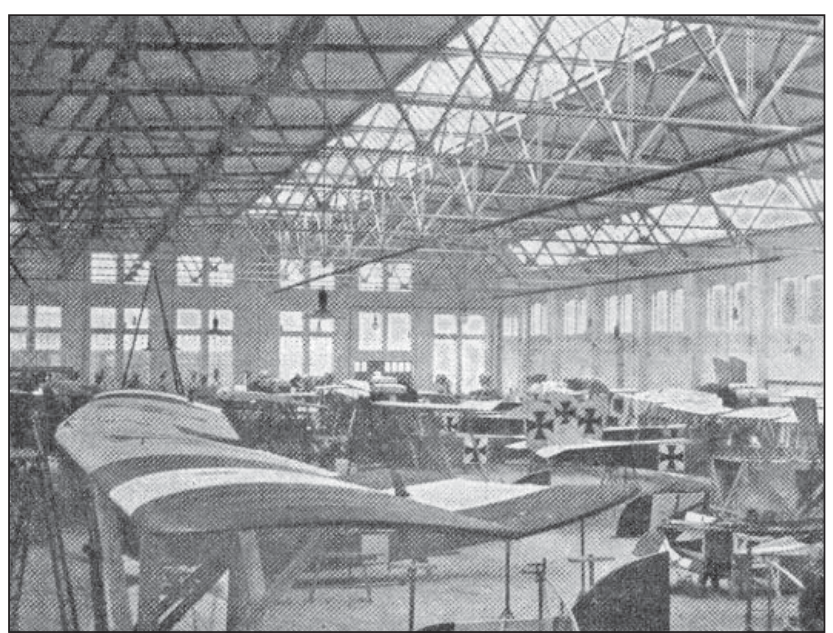

4. ábra. Szerelőcsarnok (a)

lési kapacitással. (Emellett az UFAG és a MÁG rendelkezett még nagyszámú szakképzett repülőipari alkalmazottal. Szerk.) Ilyen gyártási volumen mellett számos jól képzett szakemberre és munkásra volt szükség, létszámuk 1917ben már 700 főt tett ki. A szakmunkások csak kis része került ki aszódi, helyi lakosokból, nagyobb részük sorkatona volt, a segédmunkások döntő részét pedig a környező falvakból származók tették ki.

A gyár ügyes üzletpolitikájának köszönhetően tovább növelte hírnevét, 1916. október 1-én megrendezte az első aszódi repülőnapot, amellyel igencsak felkeltette a nagyérdemű érdeklődését, és magára irányította az ország figyelmét is. Az eseményre több jeles személyiség is ellátogatott. Ezen a rendezvényen számos újdonságot mutattak be, köztük olyan hadititoknak minősülő fejlesztéseket, amelyeket a katonai vezetés jobb szeretett volna titokban tartani. Ezért olyan megállapodás született a gyár és a katonai vezetők között, hogy a repülőnap összes bevételét a gyárnak jótékony közcélokra kellett felajánlania. A rendezvényről számos újságcikk és beszámoló adott tudósítást, így terjesztve az aszódi gyár hírnevét.

Az egész program a repülőtéren zajlott, ahol először mutatták be a publikumnak a legújabb gépeket, majd a rendezvény színesítése érdekében sétarepülésre is sor került. Ennek keretében azok a vendégek, akik kifizették a repülöutat, a pilótákkal elmehettek egy-egy 10 perces sétarepülésre. A repülőnapi vigasság nagyon jól sikerült, hatalmas bevételt hozott, több mint 4000 koronát gyűjtöttek. A repülőnap így tovább növelte a Lloyd gyár hírnevét és egyben

\section{5. ábra. Szerelő́csarnok (b)}

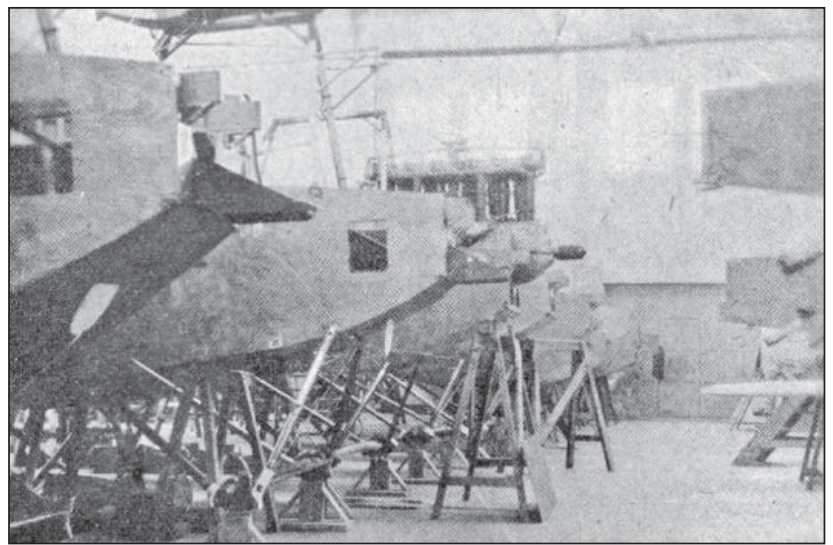

jó háborús propagandaként is szolgált. Az embereket fellelkesítette, és bizakodóvá tette a háborúval kapcsolatban, ami a világháború harmadik évében igen jót tett a közhangulatnak.

A háború még nagyobb erőforrásokat igényelt, s ezeket döntően a hadiipar emésztette fel, a nagy hadiipari beruházások miatt. A fegyverkezési verseny arra sarkallta a harcban álló feleket, hogy egyre modernebb eszközöket, és minél nagyobb számban bocsássanak ki. Ez, természetesen maga után vonta a hadiipar rohamszerű fejlődését is, hatalmas mennyiségü pénzt invesztálva a repülőgépiparba.

A Lloyd repülőgépgyárat is ezen megfontolások miatt fejlesztették, először 1916-ban, majd 1917-ben ismételten. Az 1917-es évben az alaptőkét 5 millió koronára emelték fel, és ahogy az újságok hírül adták, hatalmas építkezésekbe kezdtek. Ekkor már 2000 munkást kívántak bevonni a termelésbe, hogy a monarchia legnagyobb gyárává tegyék, napi 4 gépre emelve a gyártási kapacitást. (A háború utolsó éveire jellemző gazdasági helyzet azonban már nem tette lehetővé a tervek teljes körű megvalósítását. - Szerk.)

A Lloyd gyárat igen nagy megtiszteltetés érte, ugyanis 1917. április 29. és május 28. között, a városligeti iparcsarnokban megrendezett hadirepülőgép-kiállításon a csarnok főhelyén állították ki a Brandenburg-Lloyd-gépet, amellyel Henrik Bier magassági világrekordot állított fel. Később ezt a gépet a Közlekedési Múzeumnak adományozták, ahol azt még most is őrzik, és a múzeum átépítésének befejezése után bárki számára ismét megtekinthető lesz. A kiállításon ezen kívül bemutattak további két gépkonstrukciót is. Az egyik egy kétüléses, a másik pedig egy együléses harci gép volt.

A repülőgép-kiállítás elhozta a legnagyobb elismerést a Lloyd gyár számára, mivel az egyik aranydíjat ők vihették haza a neves rendezvényről, beírva a gyár nevét a legjobbak közé.

Ez az elismerés nagyon fontos volt a vállalat számára, ugyanis nemcsak a gyár munkásságára hívta fel a figyelmet, hanem a szakma is lerótta tiszteletét az újítások, új konstrukciók, valamint az egész gyár színvonalas működése előtt.

Mindezek után nem sokkal, 1917. május 29-én megrendezték a második aszódi repülőnapot. Ez a mulatság még az első repülőnap sikereit is felülmúlta, sokkal nagyobb és pompásabb volt. A rendezvényen még a társadalmi elit is képviseltette magát, a rendezvény fővédnökségét Auguszta főhercegnő vállalta el, s megjelent maga IV. Károly király is. Bier parádés üzleti érzéke révén különvonatokat béreltek, és ezekkel biztosították a fővárosból érkező érdeklődők eljutását a helyszínre. Az esemény rengeteg embert vonzott, annak ellenére is, hogy a belépőjegyárak nem számítottak épp kedvezményesnek.

A második aszódi repülőnap is hasonlóan jó reklámfogásnak bizonyult, mint az első. Sőt, még felül is múlta azt. A részvénytársaság igazán elégedett lehetett, hiszen a rendezvény körül keltett hírverés, valamint a reklám, is a malmukra hajtotta a vizet. A nagy felhajtást kihasználva jövedelemnövelés céljából - fémből jelvényeket készíttetett a gyár címerével és ezzel a húzással tekintélyes bevételre tett szert. A gyárnak ebben az időben azonban a repülőnapon összegyújtött pénz nélkül is stabil bevétele volt, hiszen folyamatosan kapta a megrendeléseket, a háború újabb és újabb harci gépeket követelt meg, és az állam folytonos megrendelésekkel bombázta a gyárat. Ez az időszak jelentette a gyár virágkorát. Jelentős teljesítménnyel működött a hadiipar, a gyár ontotta az elkészült gépeket, hihetetlen mértékü profitot termelt. Nem is csoda, hiszen egy gép ára jócskán meghaladhatta akár a 120000 koronát is. Több 
típusú gép, pl. a C.II., C.III., C.IV. C.VL., típusjelzésű repülők sorozatgyártása folyt akkoriban. (Ezekből egy adott időszakban egy típus épült. - Szerk.)

A gyár növekedése és gyarapodása megállíthatatlannak tűnt, monumentális hangárok épültek, újabb szerelőcsarnokokkal bővítették az épületet, 300 LE-s gőzgépközpont gondoskodott a villamos ellátásról, saját vízmúvel büszkélkedhetett az üzem, s egyéb fejlesztéseket is végrehajtottak. Az üzem a maga korában igencsak modernnek számított és korszerüsége révén biztosította a precíz termelést és a megfelelő termelékenységet, valamint megbízhatóságot. Több kiszolgáló épületet is akkoriban emeltek, ilyenek voltak az irodaközpontok és a munkásokat kiszolgáló kantin is. Ezek az épületek a mai napig használatban vannak. Szükség is volt rájuk, hiszen a monarchia, sőt KözépEurópa egyik legnagyobb és legmodernebb gyára több mint 700 munkást foglalkoztatott, akiket csak „lojdista” néven emlegettek. (A technológiai fejlődés korlátját jelentette ugyanakkor, hogy a gyár teljes mértékben faépítésre volt berendezkedve, ami gátolta egyes fém szerkezeti elemek bevezetését. - Szerk.)

Ők voltak a gyár szíve, nélkülük a cég nem érhetett volna el ilyen nagy sikereket, s ezek az emberek az 1917-es évtől kezdődően a háború-ellenes mozgalmakban, sztrájkokban is fontos részt vállaltak. Sőt, az 1918-19-es forradalomban is komolyan képviseltették magukat, ám a termelés azokban a hónapokban sem szünetelt, folytatták a gyártást és nem sejtették a tragikus végkimenetel közelségét.

\section{A HANYATLÁs}

Az 1918-19-es forradalmat követően nem váratott sokat magára a szomorú végítélet, hiszen a román megszállás utáni összeomlás magával rántotta a Lloyd-gyárat is. Leállították a termelést, s a trianoni békeszerződés hivatalosan is rányomta bélyegét a cégre, pusztulásba taszítva a gyá-
1. táblázat. A Magyar Lloyd Repülőgép és Motorgyár Rt. által gyártott repülögépek száma (forrás:[8])

\begin{tabular}{|l|c|}
\hline \multicolumn{1}{|c|}{ Repülögép típusok } & Gyártott mennyiség \\
\hline Lloyd C.I. (41. sorozat) & $1+12 \mathrm{db}$ \\
\hline DFW B.I. összeszerelés & $10 \mathrm{db}$ \\
\hline Lloyd C.II. (42. sorozat) & $70 \mathrm{db}$ \\
\hline Lloyd C.III. (43. sorozat) & $8 \mathrm{db}$ \\
\hline Lloyd C.IV. (43,5 sorozat) & $47 \mathrm{db}$ \\
\hline Lloyd C.V. (44. sorozat) & $48 \mathrm{db}$ \\
\hline Aviatic C.I. (47. sorozat) & $47 \mathrm{db}$ \\
\hline Aviatic D.I. & $\mathrm{n} . \mathrm{a}$. \\
\hline Phoenix C.I. & $6 \mathrm{db}$ \\
\hline
\end{tabular}

rat. Hiszen, háborús nagyüzemként nem müködhetett tovább, létét veszélyesnek tartották az antant hatalmak.

A békediktátum az enyészetbe küldte a hajdan virágzó repülőgépgyárat, amiből csak a régi, letűnt idők árnyéka köszönt vissza. Néhány évig faipari termeléssel foglalkozott a gyár, a tetemes raktáron lévő fát felhasználva, de ez csak a régi ipari tevékenység megcsúfolása volt, nem pedig komoly gyártási feladat. Az 1920-as évek közepére elrendelték a gyár lebontását, egyedül a kantin- és az irodaépületnek kegyelmeztek. A mindössze 10 évig tartó siker után a földdel vált egyenlővé a hajdan szebb napokat és óriási sikereket megélt gyár, amely Aszód történetének talán legszebb ékköve volt. (Az adatok alapján 20 db kísérleti repülőgépet is építettek, de számozásuknak csak a 40.01-től 40.16-ig van nyoma. Fennállása alatt, a gyárban 238 db saját gyártású repülőgép készült. Emellett 102 db Lloyd repülőgépet az ausztriai WKF cég gyártott le. Ez a mennyiség a Magyar Királyság repülőgép-gyártásában $11,7 \%$-ot tett ki. - Szerk.)

\section{6. ábra. Lloyd C.I-es repülögép}

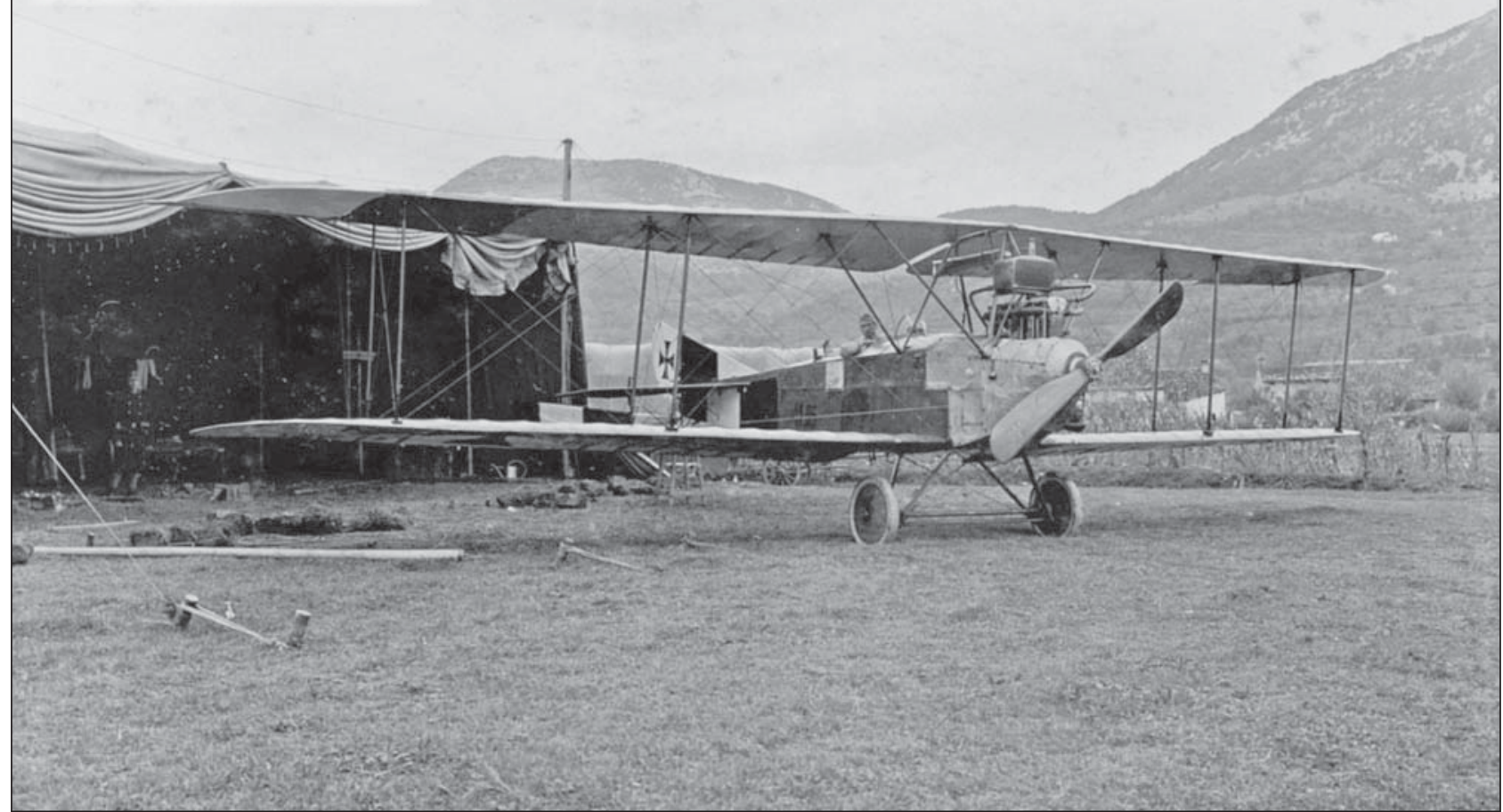


A Magyar Lloyd RePüLőgép és Motorgyár Rt. Által GYÁRTOTT REPÜLÖGÉPEK

\section{LLOYD C.I}

Ezek igen biztonságos gépek voltak, amelyeket fegyvertelen felderítésre használtak a Balkánon, az Isonzo-fronton, Karintiában és Tirolban. Ez a típus az egész monarchián belül nagy újdonságnak számított, hiszen egyedüliként tudta elérni a 4000 méteres magasságot, ami főként akkor volt nagyon hasznos, ha hegyvidéki terep fölé küldték ki. 1916 februárjában vonták vissza a megmaradt példányokat a frontról, majd gyakorlógépként hasznosították őket (6. ábra).

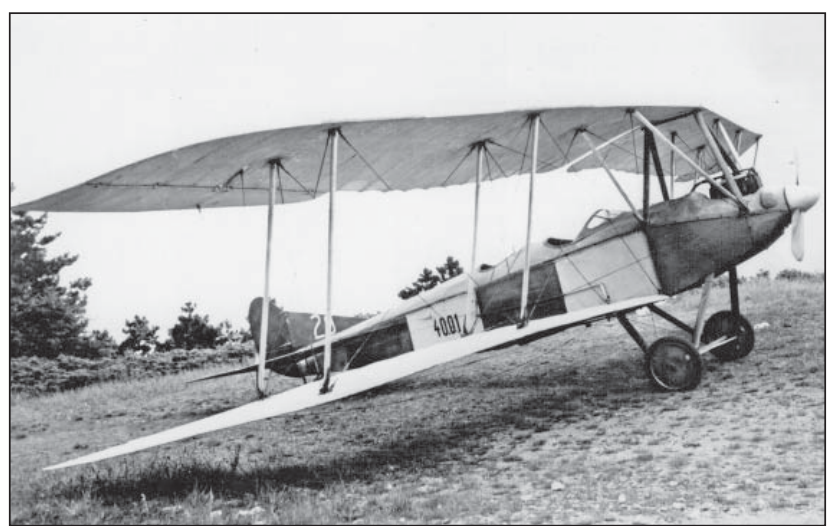

7. ábra. A 40.01-es sorozatszámú Lloyd C.I-es repülőgép

\section{LLOYD C.II}

Ezt a konstrukciót az előd, a C I típus átalakításával alakították ki. A törzs borításán, valamint a függőleges és vízszintes vezérsíkok formáján változtattak (8. ábra). Ez a tí-

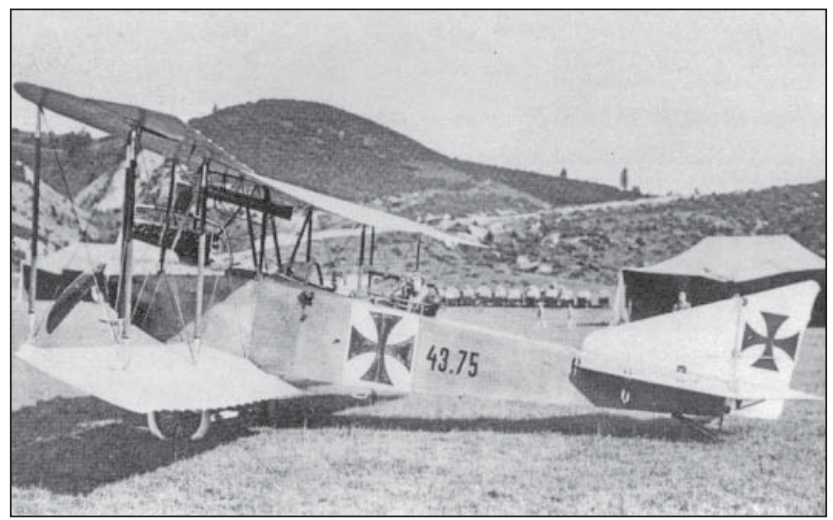

\section{8. ábra. Lloyd C.II-es repülőgép}

pus kapta végül a 42-es sorjelzést, amelyből összesen 70 darabot készített a gyár. A C.Il-es gépeket a világháború összes hadszínterén bevetették, s újítás volt az előző gépekhez képest, hogy alkalmaztak rajta géppuskát is. A fegyvert először egy fix ponthoz rögzítették, később a jól bevált körsínen lehetett mozgatni. Az 1916-os év vége felé elkezdték kivonni a C.Il-es gépeket a fontosabb harcterekről. Ez a lépés a Brandenburg C.I-es kétüléses felderítőgép megjelenése okán következett be. Ezután a Lloyd gépeket oktatógépként továbbra is alkalmazták, néhányat kétkormányos géppé alakítottak át, amelyek ugyancsak gyakorlógépként voltak használatban.

\section{LLOYD C.III}

A C.Il-es üres tömegének csökkentésével született meg a C.III-as, emellett nagyobb teljesítményű motorral is rendelkezett. Az aszódi gyár ebből a típusból csupán 8 darabot gyártott le, azonban a WKF még gyártott 43.5 sorozatszámmal 44 darabot. A Lloyd által gyártott gépek 1916 őszén kezdték meg szolgálatukat a háborúban, az újonnan megnyílt román fronton. Ezeket a gépeket - a C.I-esekhez hasonlóan - felderítő feladatokra használták, s a repülőgépvezetők egyik kedvenc gépévé vált rövid idő alatt. 1917-től ezt a típust ugyancsak gyakorlógépként használták (9. ábra).

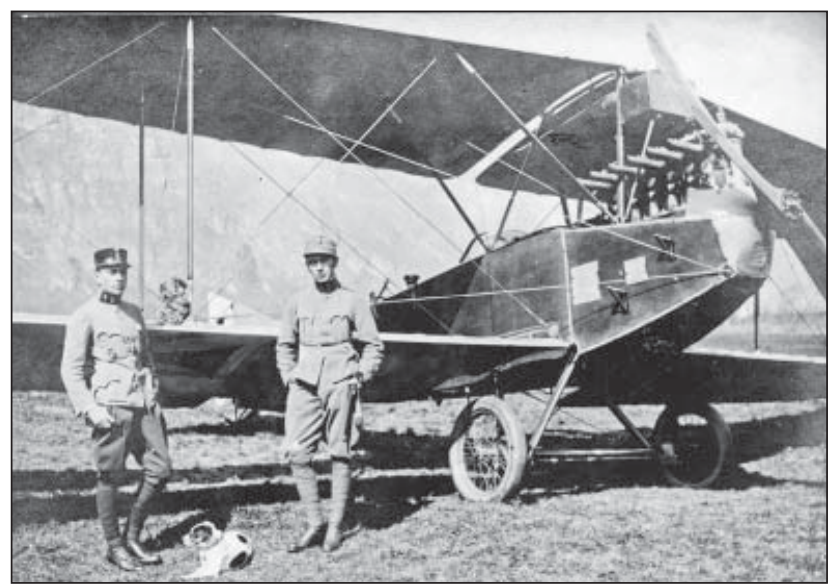

9. ábra. Lloyd C.III-as repülögép

\section{LLOYD C.IV}

Úgy tervezték, hogy ez lesz az első gép, amelyet furnérlemezes megoldással sorozatban gyártanak. Ennél a típusnál átdolgozták a szárnyformát és egycellás konstrukciót kívántak létrehozni. A szárny gyártásával azonban komoly csúszásba került a gyár, így le kellett mondani a furnérlemezes bevonásról, helyette vászonborítással látták el a szárnyakat. A típust 44-es szériának nevezték, s 1917 tavaszától a keleti frontra vezényelték a gépeket. Pár darabot az olasz frontra is küldtek, ezek gyakorló és futár feladatokat láttak el. Végül 1918 augusztusában az összes megmaradt darabot a hátországba küldték, ahol kiképzési feladatokat láttak el.

\section{LLOYD C.V}

A Melczer által megálmodott furnérborítású szárnnyal, ez a változat lett az első sorozatban gyártott gép (10. ábra). A 40.11-es oldalszámú prototípusa első felszállását 1916 októberében hajtotta végre. Ezt a gyártmányt a könnyű, de komoly igénybevételeknek ellenálló szerkezet és az áramvonalas forma jellemezte. A C.V gépeket kétféle motorral szerelték. Az aszódi gyár által készített darabok a 46-os szériaszámot viselték. A 185 LE Austro-Daimler-motorral készült gépek a 46.01-46.48-ig terjedő számozással, míg a 220 LE-s Benz-motorral rendelkező gépeket a 46.51-46.96 sorozatszámmal vezették be. A 40.11-es prototípus számát 46.01-re változtatták, s az orosz frontra küldték a Flik13-hoz. A C.V-ös szériából a Lloyd gyárban 95 darabot, míg a WKF-nél 48 gyártmányt készítettek el. Ezek a gépek rendkívül gyorsak, kisebb méretűek és erősebb szerkezetűek voltak az előző típusoknál. Előnyös tulajdonságai a 
2. táblázat. A Lloyd gépek adatai (forrás:[2])

\begin{tabular}{|l|l|c|c|c|c|c|}
\hline \multicolumn{1}{|c|}{ Típus } & \multicolumn{1}{|c|}{ Motor } & $\begin{array}{c}\text { Szárny- } \\
\text { terjedtség } \\
{[\mathrm{m}]}\end{array}$ & $\begin{array}{c}\text { Törzs- } \\
\text { hosszúság } \\
{[\mathrm{m}]}\end{array}$ & $\begin{array}{c}\text { Magasság } \\
{[\mathrm{m}]}\end{array}$ & $\begin{array}{c}\text { Maximális } \\
\text { felszálló tömeg } \\
{[\mathbf{k g}]}\end{array}$ & $\begin{array}{c}\text { Maximális } \\
\text { sebesség } \\
{[\mathbf{k m} / \mathrm{h}]}\end{array}$ \\
\hline Lloyd C.I & 145 LE Hiero & 14,4 & 8,9 & 3,14 & 1250 & 115 \\
\hline Lloyd C.II & 145LE Hiero & 14,0 & 9,0 & 3,16 & 1329 & 128 \\
\hline Lloyd C.III & 160 LE Austro-Daimler & 14,0 & 9,0 & 3,16 & 1310 & 133 \\
\hline Lloyd C.IV & 160 LE Austro-Daimler & 14,52 & 8,79 & 3,18 & 1334 & 133 \\
\hline Lloyd C.V & 185 LE Austro-Daimler & 11,2 & 7,22 & 3,0 & 1125 & 165 \\
\hline Aviatik C.I & 185 LE Austro-Daimler & 8,4 & 7,15 & 2,6 & 1016 & 170 \\
\hline Aviatik D.I & 225 LE Austro-Daimler & 8,0 & 6,88 & 2,45 & nincs adat & 185 \\
\hline Phönix C.I & 230 LE Hiero & 11,0 & 7,52 & 2,95 & 1240 & 175 \\
\hline
\end{tabular}

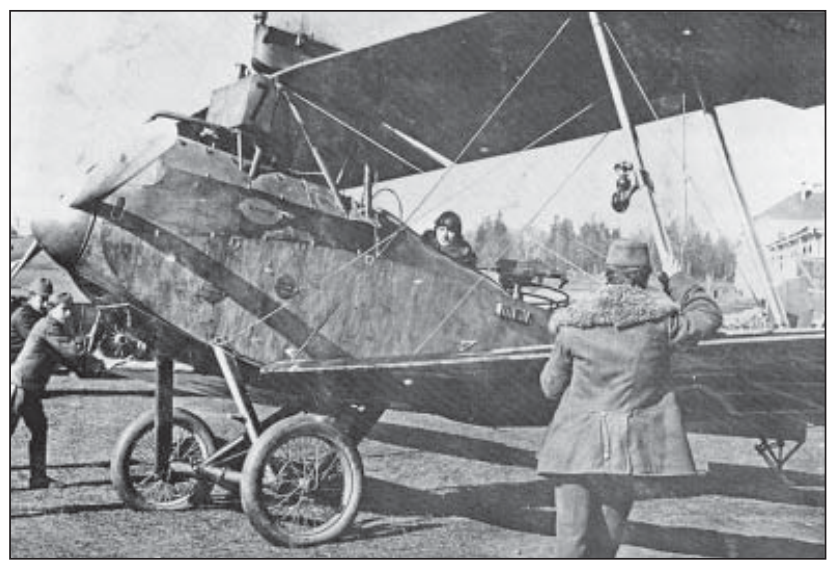

10. ábra. Lloyd C.V-ös repülőgép

vadászgépekhez tették hasonlatossá. Zuhanáskor nagyon jól gyorsult, leszállósebessége is jelentős volt. A kormányvezérlő rendszere nagyon érzékeny volt, minden rezdülést érzékelt még kis sebességű repülésnél is. Emiatt a tulajdonsága miatt kevésbé kedvelték, hiszen az általuk megszokott repülőgépek jóval lomhábbak és könnyebben vezethetők voltak. A frontvonalakon pont ezért a Brandenburg C.I-es gépeket preferálták jobban, s a Lloyd C.V-ösök inkább futárfeladatokat láttak el, valamint gyakorlógépként is alkalmazták. A gépeket megfigyelő-géppuskával, és ritkán a szárny felett tüzelő géppuskával is ellátták, bombák szállítására is alkalmas volt, valamint a sorozat-fényképező kamerát és a rádiót a megfigyelő mögé beépítették a törzsbe.

\section{AVIATIK C.I.}

Az Aviatik C.l-es repülőgép születése a monarchia által először tervezett vadászgépéhez, az Aviatik D.I-eshez köthető. Ezek a gépek már új kategóriát képviseltek a repülőgépek között, és gyorsfelderítőként alkalmazták őket. Jellemzői között megtalálható a kis szárnyterjedtség és a nagy teljesítményú motor. Ezen jellemzők nagy repülési sebességek elérését tették lehetővé. Felszereléséhez tartozott egy forgatható megfigyelö és egy mereven előretüzelő szinkronizált géppuska, valamint az alsó szárnyak alatt bombák rögzítésére is volt lehetőség. Ez a típus a Flik 59 D-nél szolgált, amelynek parancsnoka Lukács Károly százados volt. A tesztrepülések alapján az Aviatik C I-es ideálisnak bizonyult, minden kívánalomnak megfelelt, ezért a monarchia repülőgépgyárainak kiadták ezen gépek gyártásának feladatát. Aszódon összesen 47 darab Aviatik C I-es készült, s ezek a 47-es számozást kapták megjelölésül.

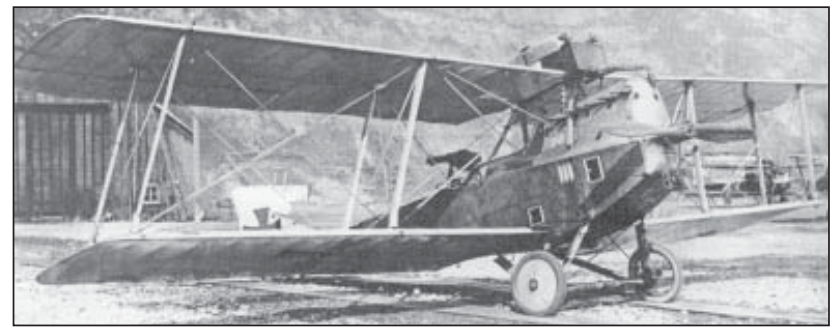

11. ábra. Aviatik C.I-es repülőgép

\section{AVIATIK D.I}

Ez volt az első önállóan tervezett konstrukció, ezért presztízskérdés volt ennek a megfelelő gyártása. A feladattal a monarchia tíz repülőgépgyárából hatot bíztak meg. Tulajdonságai a legjobb gépek közé emelték a D.I-es modellt. Jól fordultak, gyorsak voltak, gyorsabbak, mint az ellenség akkori legmodernebb gépei. Az aszódi gyárban három szériában folyt a gyártás, amelyek a 48-as, a 248-as és a 348 -as sorozatok voltak. A legerősebb gépeket, a 348-as sorozatot 225 LE Daimler (MẢG) motorral láttak el. Azonban ezeket a repülőgépeket már nem adhatták át, mert a fegyverletétel ezt nem tette lehetővé. Az első magyar felségjelzés a szárnyakon és a törzsön feltüntetett ék alakú

12. ábra. Aviatik D.I-es repülögép

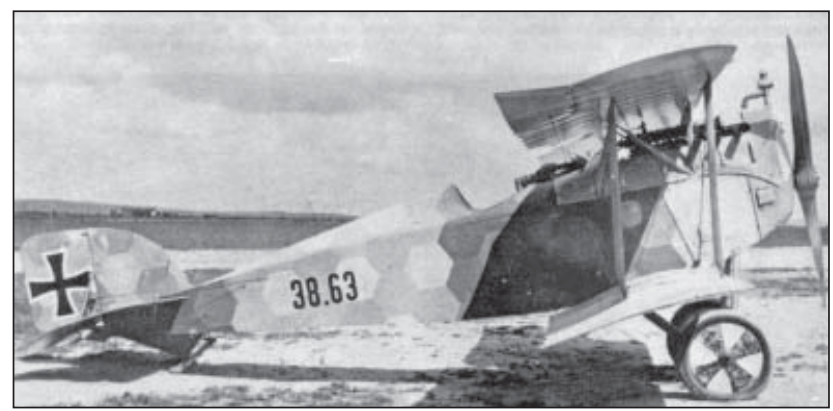




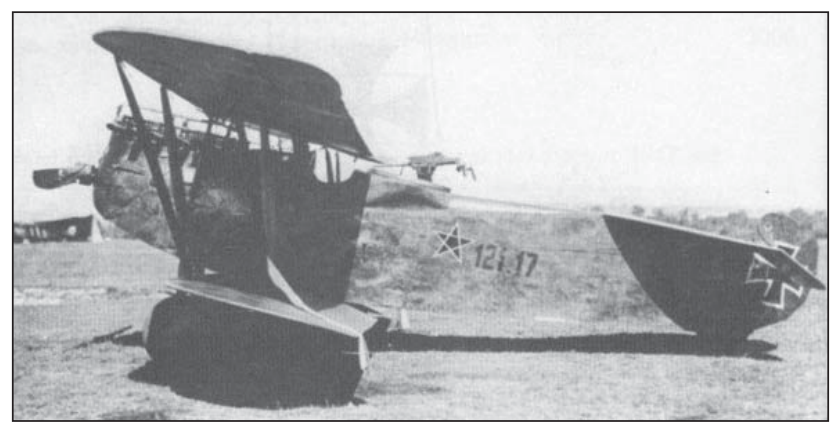

13. ábra. Phönix C.I-es repülögép

trikolor volt, ezt a 348.48-as gépen vezették be. Ezt a jelzést 1919 márciusában a vörös csillagos jelzés váltotta, és a 348.45-ös, 348.46-os és a 348.49-es gépek a 4. Vörös Repülőszázadhoz kerültek. A Magyar Aeroforgalmi Rt. (MAEFORT) gépei között is megtalálható volt 4 darab, amelyeket gyors postagépként alkalmaztak.

\section{PHÖNIX C.I}

Ez a repülö is a gyorsfelderítő gépek csoportjába tartozik. Ez a gép vált a legkedveltebb géppé, s csupán ennek a gépnek a gyártását kívánta folytatni a monarchia 1919 márciusa után. Ez a típus a világháború végeztével is tovább szolgált Magyarországon és Svédországban. A Phönix C.I-es nagyon kényelmes, könnyű repülést biztosító gép volt. Jól emelkedett, nagy magasságban is megőrizte előnyös tulajdonságait. Fegyverzete egy előretüzelő szinkronizált géppuskából, és a megfigyelő számára mozgatható fegyverből állt. A fegyvereken kívül ellátták még bombák rögzítésére alkalmas rögzítéssel, amellyel akár 100 kg-nyi bombát is szállíthatott. Az aszódi Lloyd gyárnál a Phönix C.I-esből az első világháború végéig csak néhány darabot készítettek el, gyártása azonban a Tanácsköztársaság ideje alatt is folytatódott. Ezek a gépek azonban nem az eredeti 230 LE Hiero motorokkal kerültek ki, hanem a MÁG gyártású, 200 LE-s Austro-Daimlerekkel. 1919-ben részt vettek a román és cseh csapatok elleni összecsapásokban. A gépeket 1921-ben, a trianoni békeszerződés értelmében meg kellett semmisíteni.

(Köszönetnyilvánítás: A tanulmány az Új Nemzeti Kiválóság Program keretében készült.)

\section{FELHASZNÁLT IRODALOM}

[1] Asztalos István: Kisváros a Galga mentén - Aszód város története 1944-ig, Aszód Város Önkormányzata, Aszód, 1977;

[2] Horváth Fruzsina: Az Aszódi Fiúnevelő Intézet technikatörténete, tudományos diákköri dolgozat, (Konzulens: Moharos István), ÓE BGK, 2007.;

[3] Nagyváradi Sándor - M. Szabó Miklós - Winkler László: Fejezetek a magyar katonai repülés történetéből, Műszaki Könyvkiadó, Budapest 1986;

[4] Szabó József: Repülési lexikon, Akadémiai Kiadó, Budapest, 1991;

[5] Szabó József: A Galambtól a Griffmadárig, a magyar katonai repülés 100 éve, HM Térképészeti Közhasznú Nonprofit Kft., Budapest, 2010;

[6] Treadwell, Terry C.: German and Austro-Hungarian Aircraft Manufacturers, 1908-1919, Amberley Publishing Limited, 2010., Ungarische Lloyd Flugzeug und Motorenfabrik AG.;

[7] Aszód Városi Kulturális Központ, Petőfi Közérdekű Muzeális Gyűjtemény archívuma;

[8] Punka György - Sárhidai Gyula - Zsák Ferenc: Légi győzelmek és veszteségek 1914-1945. Kornétás Kiadó, Budapest, 2017.

\section{HM ZRÎNYI TÉRKÉPÉSZETI ÉS KOMMUNIKÁCIÓS SZOLGÁLTATÓ KÖZHASZNÚ NKFT}

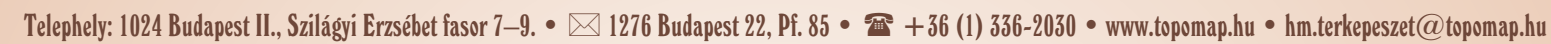

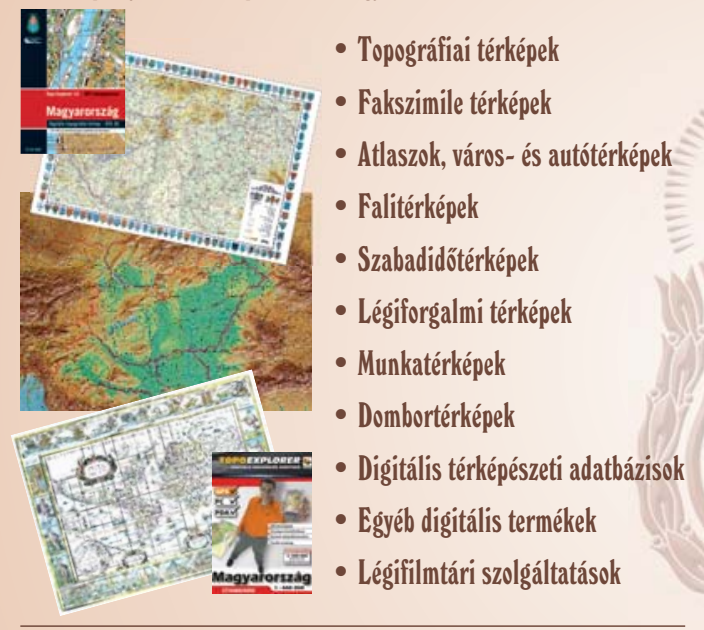

ÜGYFÉLSZOLGÁLAT ÉS TÉRKÉPBOLT:

1024 Budapest II., Fillér u. 14.

疋 +36 (1) 212-4540・uǵffelszolgalat@topomap.hu Nyitva tartás: hétfo"-péntek 9.00-15.00
- PrePress - Nyomdai elökészítés

- szöveg-, grafika- és képfeldolgozás, kiadványszerkesztés

- ellenőrző nyomatok, digitális proofok előállítása

- bel-és kültéri tablók, bannerek nyomtatása

- hagyományos és elektronikus montírozás, színrebontás

- nyomóformák elóállítása nyomdai filmról, illetve CTP-technológiával

- Gyorssokszorosítás

- színes és fekete-fehér másolás/nyomtatás 330 x 487 mm méretig

- Press - Nyomtatás

- ofszetnyomtatás négy-, illetve hatszínnyomó gépeken, 89 x 126 cm méretig

- PostPress - Kötészeti feldolgozás

- feliuletnemesítés fóliázással, laminálással 167 cm szélességig

- hajtogatás, spirálozás, sorszámozás

- összehordás, irkakészítés, ragasztókötés

- kasírozás, táblakészítés, aranyozás

- szortiment könyvkötészet

- Vákuumformázás

- vákuumformázó szerszámok, terepasztalok elóállítása CNC-technológiával - vákuumformázás

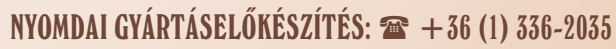

